\title{
Thin-Film Cadmium Telluride Photovoltaics: ES\&H Issues, Solutions, and Perspectives
}

Ken Zweibel, NREL

Paul Moskowitz, BNL

Vasilis Fthenakis, BNL

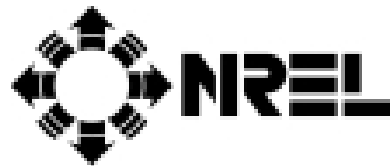

National Renewable Energy Laboratory

1617 Cole Boulevard

Golden, Colorado 80401-3393

A national laboratory of the U.S. Department of Energy

Managed by Midwest Research Institute

for the U.S. Department of Energy

under contract No. DE-AC36-99-GO10337

Prepared under Task no. PV804401

February 1998 


\section{NOTICE}

The submitted manuscript has been offered by an employee of the Midwest Research Institute (MRI), a contractor of the US Government under Contract No. DE-AC36-99G010337. Accordingly, the US Government and MRI retain a nonexclusive royalty-free license to publish or reproduce the published form of this contribution, or allow others to do so, for US Government purposes.

This report was prepared as an account of work sponsored by an agency of the United States government. Neither the United States government nor any agency thereof, nor any of their employees, makes any warranty, express or implied, or assumes any legal liability or responsibility for the accuracy, completeness, or usefulness of any information, apparatus, product, or process disclosed, or represents that its use would not infringe privately owned rights. Reference herein to any specific commercial product, process, or service by trade name, trademark, manufacturer, or otherwise does not necessarily constitute or imply its endorsement, recommendation, or favoring by the United States government or any agency thereof. The views and opinions of authors expressed herein do not necessarily state or reflect those of the United States government or any agency thereof.

Available electronically at http://www.osti.gov/bridge

Available for a processing fee to U.S. Department of Energy and its contractors, in paper, from:

U.S. Department of Energy

Office of Scientific and Technical Information

P.O. Box 62

Oak Ridge, TN 37831-0062

phone: 865.576 .8401

fax: 865.576 .5728

email: reports@adonis.osti.gov

Available for sale to the public, in paper, from:

U.S. Department of Commerce

National Technical Information Service

5285 Port Royal Road

Springfield, VA 22161

phone: 800.553 .6847

fax: 703.605.6900

email: orders@ntis.fedworld.gov

online ordering: http://www.ntis.gov/ordering.htm 


\section{Thin-Film Cadmium Telluride Photovoltaics: ES\&H Issues, Solutions, and Perspectives}

Photovoltaics (PV) is a growing business worldwide, with new technologies evolving towards potentially large-volume production. PV use produces no emissions, thus offsetting many potential environmental problems. However, the new PV technologies also bring unfamiliar environment, safety, and health $(E S \& H)$ challenges that require innovative solutions. This is a summary of the issues, solutions, and perspectives associated with the use of cadmium in one of the new and important PV technologies: thin-film, cadmium telluride (CdTe) PV, which is being developed and commercialized by several companies including Solar Cells Inc. (Toledo, Ohio), BP Solar (Fairfield, California), and Matsushita (Japan).

The principal ES\&H issue for thin-film cadmium telluride PV is the potential introduction of cadmium - a toxic heavy metal - into the air or water. The amount of cadmium in thin-film PV, however, is quite small — one nickel cadmium flashlight battery has about as much cadmium ( $7 \mathrm{~g}$ ) as a square meter of PV module using current technology (see discussion below) - and a typical cordless power tool will have 5-10 batteries. CdTe modules are also very well sealed, limiting the chance of release. Nonetheless, minimizing the amount of cadmium in cadmium telluride modules and preventing the introduction of that cadmium into the environment is a top priority for National Renewable Energy Laboratory researchers and cadmium telluride PV manufacturers.

\section{The Amount and Nature of Cadmium in CdTe PV}

A thin CdTe semiconductor layer is essential to the performance of the CdTe PV technology. As such, it cannot be eliminated. However, the amount of CdTe can be quite minimal. Today, about 2-5 microns of CdTe - already a very small amount - are used in CdTe products. However, only about 0.5 microns are needed to effectively absorb sunlight for the solar device to perform. Indeed, known engineering approaches associated with trapping light within semiconductors suggest that the ultimate thickness of CdTe layers could be as little as 0.2 microns. Table 1 summarizes the amount of $\mathrm{Cd}$ in $\mathrm{CdTe}$ products based on these different layer thicknesses:

Table 1. The Amount of Cadmium in CdTe Layers of Various Thicknesses

\begin{tabular}{|l|l|l|l|l|l|}
\hline & 5 microns & 2 microns & 1 micron & 0.5 micron & 0.2 micron \\
\hline $\mathrm{g} / \mathrm{m}^{2}$ & $14 \mathrm{~g}$ & $5.5 \mathrm{~g}$ & $2.75 \mathrm{~g}$ & $1.4 \mathrm{~g}$ & $0.55 \mathrm{~g}$ \\
\hline
\end{tabular}

There is a very thin CdS layer in CdTe products. Its thickness is small (under 0.1 micron) and getting smaller. It is not an essential part of the device and is likely to either disappear or be minimized to under 0.03 micron when the technology is mature. At that thickness, it would contribute another $0.1 \mathrm{~g} / \mathrm{m}^{2}$ to a CdTe product. In addition, film fabrication processes are not $100 \%$ efficient. They cannot deposit $100 \%$ of the $\mathrm{Cd}$ on a PV device; some small percentage is wasted during processing, and some further amounts are wasted because production yields are also imperfect. Thus, about 25\%-50\% more Cd feedstock than shown in Table 1 will be needed for each square meter of module. We estimate that between $1-2 \mathrm{~g} / \mathrm{m}^{2}$ would be needed for a mature technology. 
Is $1-2 \mathrm{~g} / \mathrm{m}^{2}$ a lot of cadmium? Consider the following:

- There are 20,000 MT of Cd used worldwide each year, about half for Ni/Cd batteries [1,2]. If used for PV, 20,000 MT/yr (@2 g/m $\mathrm{m}^{2}$ )would supply about $10^{10} \mathrm{~m}^{2}$ of new PV annually, which at $10 \%$ sunlight-to-electricity conversion efficiency would produce $1000 \mathrm{GW}_{\mathrm{p}}$ of new PV capacity per year, and approximately 1.6 million GWh of new PV electricity each year. The U.S. utility grid produces about 3 million GWh of electricity each year, so 2 years of using the world's Cd would displace the entire U.S. electricity grid! And PV modules are designed to last 30 years.

- Using a more practical example of how large-scale PV might develop, at $1000 \mathrm{MT} / \mathrm{year} \mathrm{Cd}$ ( $5 \%$ of world Cd use), 500 million $\mathrm{m}^{2} /$ year of CdTe PV could be manufactured (at $10 \%$ efficiency), producing $50 \mathrm{GW}_{\mathrm{p}} /$ year of new PV $(80,000 \mathrm{GWh} / \mathrm{yr}$ of added electricity). In only four years, this would result in the equivalent of $10 \%$ of U.S. electricity being produced with PV (about the same as hydropower and half as much as nuclear power). Compare this with the current use of most $\mathrm{Cd}$, which is to provide battery power for home electronics and toys.

In summary, using cadmium for PV has tremendous potential value to change the world's energy infrastructure and ameliorate existing environmental problems resulting from the use of conventional energy sources.

\section{In-Plant Energy Use, Safety, and Recycling}

Some cadmium ends up on the walls of reactors; some remains as partially used feedstock; and more can be found in partial layers on rejected, incomplete modules. These feedstock losses must be dealt with via disposal or recycling. Because of the success of two U.S. Department of Energy (DOE) Small Business Innovation Research (SBIR) grants to U.S. small businesses (Solar Cells, Inc. and Drinkard Metalox), technology has been developed for recycling both in-plant wastes and "spent" CdTe modules [3]. This new process separates the various metal, glass, and pottant layers so that they can be individually recycled. In addition, cadmium suppliers are willing to take back cadmium wastes for re-smelting and recovery. Finally, glass manufacturers are also willing to recycle broken glass [4]. For each type of process, techniques are being developed for cleaning and waste minimization or recycling. In all cases, the best possible procedures are being developed to minimize exposure during manufacture or cleaning. Current approaches to CdTe manufacture can easily meet today's Occupational Safety and Health Administration and state and local in-plant ES\&H regulations.

\section{Product Distribution and Use}

PV modules are sealed to prevent the ingress of water vapor or any other potentially harmful influences. This is done to protect the metal contacts from corrosion, which would cause the modules to lose power or fail. Because modules can be effectively sealed, they carry warranties for as much as 20 years or more. This highly effective sealing also keeps PV modules from leaching material to the environment [10] unless artificially ground into very small pieces. In fact, semiconductors such as CdTe are among the most stable and impervious materials known: CdTe is nonflammable and melts at over $1000{ }^{\circ} \mathrm{C}$. Fires are considered a potential hazard, but studies [9] indicate that CdTe modules have so little material and are basically so inert that they add almost negligibly to residential fire hazards. It is likely, for example, that there would be nearly as much cadmium inside a burning home (in chemical form, within batteries) as in solid, inert form on a rooftop covered with CdTe modules. A rooftop installation about $50 \mathrm{~m}^{2}$ of PV modules - enough to meet an average household's total electrical needswould contain about 500 grams of cadmium, about the amount in 10 cordless power tools. It is also likely that severe dangers from fires - e.g., smoke from burning furniture - could be far deadlier than any source of cadmium fumes. 


\section{Product Disposal and Recycling}

What happens to PV modules at the end of their use? First, because modules are expected to last about 30 years, wastes are minimized. Technology already exists for recycling CdTe modules, and costs associated with recycling appear to be acceptable (approximately 5 cents/W) [4,5]. The feasibility of PV module collection and recycling has been extensively studied by Brookhaven National Laboratory and Unisun [11,12]. Patterns of collection and recycling from other industries, such as electronics, can be paradigms for future PV collection and recycling. Also, large-scale collection and recycling can be done with reverse-logistics companies (collection, moving, and delivery companies that need freight for underutilized return trips) and metal smelters. In addition, manufacturing plants can implement small-scale recycling for their PV scrap, using technologies currently being developed by the DOE SBIR Program.

How big is the cadmium disposal problem? Today's utility coal plants not only produce more familiar pollutants; they also produce heavy-metal pollution. Among these pollutants are cadmium, which goes up the stack in quantities of about $4 \mathrm{~g} / \mathrm{MWh}[6]$. This material enters the environment in vapor form. What about CdTe PV? One square meter of module at $10 \%$ efficiency produces $180 \mathrm{kWh}$ in an average U.S. location each year. In 30 years, it would produce about $5000 \mathrm{kWh}$. If there are $2 \mathrm{~g}$ of $\mathrm{Cd}$ used to make the module, PV would use $0.4 \mathrm{~g} / \mathrm{MWh}$, one-tenth the amount sent up the stack by coal burning. Meanwhile, the module would be using an inert form of cadmium that can be recycled. The U.S. Environmental Protection Agency (U.S. EPA) reports that coal burning is by far the largest source of atmospheric cadmium [7], providing more than two-thirds of identifiable air emissions ( 240 short tons/yr in 1990). By offsetting conventional sources of electricity, PV clearly reduces the impact of cadmium on the environment.

In addition, at $1000 \mathrm{MT} / \mathrm{yr}$ of cadmium use, PV would barely change the world's use of this material, which is $20,000 \mathrm{MT} / \mathrm{yr}$. Thus, the issues of Cd disposal would hardly be changed by a technology that has the potential to change the entire world's energy infrastructure.

\section{Conclusions: Overall Perspectives}

Cadmium telluride PV is an important, potentially cost-competitive PV electricity option. Like any innovative technology, it poses some new ES\&H challenges. However, PV modules contain only a very small amount of inert CdTe. The use of cadmium for PV is actually small compared to its current use in $\mathrm{Ni} / \mathrm{Cd}$ batteries. In PV, none of the cadmium material is likely to enter the environment during use, and cost-effective methods for recycling exist. Consumers face no significant risks, even under such unusual circumstances as a house fire. The use of CdTe PV modules to offset electricity that would otherwise come from conventional sources such as coal plants is clearly beneficial to the environment.

However, challenges remain. Manufacturers must demonstrate their willingness to adopt bestpossible safety practices [8]. Engineering and in-plant administrative controls are needed to prevent occupational hazards $[13,14]$ (for example, dust inhalation). Technological and logistic development of product recycling must continue, especially during the early period when disposal/recycling will be minimal. And, finally, researchers must fully develop the use of very thin layers to minimize cadmium use.

If economically successful, CdTe PV technology should provide substantial relief from existing environmental stresses. The issues associated with the use of cadmium should be manageable and small compared to the positive offsets of using PV to produce our electricity. 


\section{References}

1. Mineral Commodity Summaries 1989, U.S. Geological Survey, p. 33.

2. Nickel-Cadmium Battery Update 90, Report on the Brussels Seminar, September 1990, Cadmium Association, London, UK, p. 7.

3. 26th IEEE PV Specialists Conference, September 29-October 3, 1997, Anaheim, California (see papers by J. Bohland, Solar Cells, Inc., and R. Goozner, Drinkard Metalox).

4. Moskowitz, P.D. and Zweibel, K. (eds.), "Recycling of Cadmium and Selenium from PV Modules and Manufacturing Wastes: A Workshop Report," Brookhaven National Laboratory, 1992.

5. Fthenakis, V.M., Eberspacher, C., and Moskowitz, P.D., "Recycling Strategies to Enhance the Commercial Viability of CIS PV," Progress in Photovoltaics: Research and Applications, 4, 447-456, 1996.

6. "Energy System Emission and Materiel Requirements," Meridian Corporation, prepared for the Deputy Assistant Secretary for Renewable Energy, February 1989 (Data Appendix).

7. Locating and Estimating Air Emissions from Sources of Cadmium and Cadmium Compounds, EPA-454/r-93-040, September 1993 (Table 3-3).

8. National PV Environmental, Health, and Safety Information Center Bibliography, available from Brookhaven National Laboratory (516-282-2017); nearly 100 references to ES\&H papers and resources.

9. Moskowitz, P.D. and Fthenakis, V.M., "Toxic Materials Released from PV Modules During Fires; Health Risks," Solar Cells, 29, 63-71, 1990.

10. Steinberger, H., "HSE for CdTe and CIS Thin Film Module Operation," Presented at the IEA Expert Workshop on Environmental Aspects of PV Power Systems, May 23, 1997, Utrecht, The Netherlands.

11. Fthenakis, V.M., Eberspacher, C., and Moskowitz, P.D., "The Feasibility of Recycling Solar Cells," submitted to IEEE Spectrum.

12. Eberspacher, C. and Fthenakis, V.M., "Disposal and Recycling of End-of-Life PV Modules," 26th IEEE PV Specialists Conference, Anaheim, California, October 1997.

13. Morgan, D.L., Shines, C.J., Jeter, S., Blazka, M., Elwell, M., Wilson, R., Ward, S., Price, S., and Moskowitz, P.D., "Comparative Pulmonary Absorbtion, Distribution and Toxicity of Copper Galium Diselenide, Copper Indium Diselenide, and Cadmium Telluride in Sprague-Dawley Rats," Toxicol. Appl. Pharmacol., in press.

14. Morris, S.C., Fthenakis, V.M., and Moskowitz, P.D., A Review of Toxicity of CeTe, CGS and $C I S$, Brookhaven National Laboratory report, in press.

\section{For More Information, Please Contact:}

Ken Zweibel, Thin Film PV Partnership, National Renewable Energy Laboratory (303-384-6441, ken_zweibel@nrel.gov)

Paul Moskowitz, Environmental and Waste Technology Center, Brookhaven National Laboratory (516-344-2017,pdm@bnl.gov)

V. Fthenakis, Environmental and Waste Technology Center, Brookhaven National Laboratory (516-344-2830,vmf@bnl.gov) 